\title{
Universal Design for Instruction and Learning: A Pilot Study of Faculty Instructional Methods and Attitudes Related to Students with Disabilities in Higher Education
}

\author{
R. David Black, Lois A. Weinberg, \& Martin G. Brodwin \\ California State University Los Angeles
}

\begin{abstract}
Universal design in the education setting is a framework of instruction that aims to be inclusive of different learners to reduce barriers for all students, including those with disabilities. We used the principles of Universal Design for Learning (UDL focuses on the learner) and Universal Design for Instruction (UDI focuses on instruction) as the basis for this study. The purposes of this study were to determine if faculty were incorporating UDI/UDL into their instruction, and their attitudes toward students with disabilities, as these could be barriers to learning. The study revealed that some faculty were incorporating principles of UDI/UDL into their instruction, the variety of methods used varied, and faculty attitudes still create barriers to an equitable educational environment for students with disabilities. More education and training is needed in working with students with disabilities and adapting teaching methods for these students using UDI/UDL.
\end{abstract}

Universal design in education creates an educational environment that is not just inclusive of students with disabilities, but of all students. Universal design for instruction (UDI) contains principles for curriculum development and instruction that give all individuals equal opportunities to learn. It is a framework for creating instructional goals, methods, materials, and assessments that work for everyone, and includes flexible approaches that can be customized and adjusted to meet the needs of individual students (Center for Universal Design, 1997; Roberts, Park, Brown, \& Cook, 2011). UDI involves various approaches to instruction so that students with different abilities and backgrounds can access and benefit from the educational material (Embry, Parker, McGuire, \& Scott, 2005). Universal design for learning (UDL) is another concept using universal design that focuses on the learner. It provides a means of representation, expression, and engagement of students (CAST, 2013a; Pliner \& Johnson, 2004), and is designed for a broad range of learners.

UDI and UDL are closely related in concept. Both UDI and UDL allow for inclusion of all students to learn, and each provides a set of principles and guidelines for developing instruction 
and curricula on how to achieve this goal. The principles of UDI include (a) equitable use where instruction is designed to be useful to and accessible by all learners; (b) flexibility in use where instruction provides a choice in methods of use; (c) simple and intuitive where instruction is straightforward eliminating unnecessary complexity; (d) perceptible information where information is communicated effectively to the student regardless of ambient conditions or the student's sensory abilities; (e) tolerance for error where instruction anticipates variation in individual learning pace and prerequisite skill; (f) low physical effort where instruction is designed to eliminate nonessential physical effort to allow maximum attention to learning; (g) size and space where instruction is designed regardless of a student's size, posture, mobility, and communication needs; (h) community of learners where interaction and communication among students and between students and faculty is promoted; and (i) instructional climate that is welcoming and inclusive, and high expectations are promoted for all students (Burgstahler, 2012; McGuire \& Scott, 2006b; McGuire, Scott, \& Shaw, 2003; Roberts et al., 2011). Another set of principles was developed for UDL by the Center for Applied Special Technology (CAST), which also emphasize the need for flexibility in curricula in designing courses that allow for variable means of representation, expression, and engagement (CAST, 2013a; Pliner \& Johnson, 2004).

Additionally, some UDI and UDL principles are similar. For example, the UDL principle of providing multiple means of representation also encompasses providing alternative modes of information presented to the students. This is similar to the UDI principle of flexibility in use where instruction allows for a choice in methods of use as well as the principle on perceptible information. However, they do differ in their foundation. UDL is based on neuroscience and neurocognitive fields, originally implemented in middle schools, but now expanding to other levels, including higher education (CAST, 2013b). UDI is based on research by Mace (Center for Universal Design, 2008), which focuses on environment and accessibility, and is primarily applied in the postsecondary education setting.

Incorporating principles and guidelines for universal design in faculty instruction is essential to help create a more inclusive educational environment for students with disabilities (CAST, 2013a; McGuire \& Scott, 2006b; McGuire et al., 2003; Pliner \& Johnson, 2004; Roberts et al., 2011; Schelly, Davies, \& Spooner, 2011). Education and training of teachers and faculty is also vital to lowering barriers and attitudes and increasing familiarity with students with disabilities (Harrison, 2006). Training is important for faculty to be comfortable incorporating universal design into their curricula to decrease barriers. Disability awareness including information on the accommodation process, particularly for students with hidden disabilities, helps decrease attitudinal barriers to education (Harris, Ho, Markle, \& Wessel, 2011).

Van Laarhoven, Munk, Lynch, Bosma, and Rouse (2007) evaluated attitudes of teacher candidates who received training on assistive technologies, accommodations, functional behavioural assessment, and planning lessons using UDL compared to a control group that received traditional training. Another major distinction between the training programs was the addition of clinical fieldwork experience for the experimental group where teacher candidates received training in an inclusive classroom (integration of students with disabilities into general classrooms). Attitudes toward inclusion of students with disabilities became more positive at posttest for both groups; however, attitudes of the control group were lower. This was especially true for test items about perceptions that "including students with disabilities would negatively affect needs of students without disabilities," "teaching students with disabilities is too much for regular teachers," and "special education teachers are more effective than regular teachers in teaching students with disabilities." The authors concluded that the control group scored lower in their 
ability to identify instructional accommodations for an inclusive classroom. They noted that the differences in the results between the experimental and control groups may be explained by the difference in the training programs, where the experimental group receives clinical experience in an inclusive classroom. Brown, Welsh, Hill, and Cipko (2008) found that teacher candidates who received embedded best practices instruction incorporated into their preparation compared to controls had increased awareness of inclusion terminology and assessment adaptations, as well as meeting the needs of students with learning disabilities.

In a study by Leyser and Greenberger (2008), faculty attitudes and willingness to accommodate were related to training and the degree of contact with students with disabilities. The authors found that faculty from postsecondary institutions who had more contact with students with disabilities were more willing to provide instructional accommodations. Approximately $60 \%$ reported having no training in areas of disabilities, and $40 \%$ felt they did not have the necessary skills or knowledge to make accommodations. This study indicated the need for more training and education so faculty become familiar with the increasing population of students with disabilities and properly include them in college classes, provide appropriate accommodations, and decrease attitudinal barriers.

Implementing UDI and UDL helps to alleviate some required accommodations for individual students with disabilities since the students' learning needs are already being incorporated into the instructional design of the class (Rao \& Tanners, 2011). The literature has described the perceptions of university faculty in terms of how familiar or unfamiliar they are about the needs of students with disabilities (Eilola et al., 2011; Humphrey, Woods, \& Huglin, 2012; Izzo, Murray, \& Novak, 2008). In a survey by Eilola et al. (2011), the authors found that a greater awareness was needed in the accommodation process of students with disabilities and that a plan is needed to promote inclusion. Other authors (Humphrey et al., 2012) found a need to establish a more meaningful and proactive relationship between students with disabilities, faculty, and the disability resource centre to understand and better meet the needs of students with disabilities. Izzo et al. (2008) found that faculty ranked UDL as the area in which they most needed training.

Surveys and focus groups have been used to study the implementation of universal design where both faculty and students perceived improved benefits and noted its potential to help improve persistence and retention of students with disabilities in postsecondary education as well as decrease attitudinal barriers (Burgstahler \& Moore, 2009; Madaus, Scott, \& McGuire, 2003b; McGuire \& Scott, 2006a; Schelly et al., 2011). Experimental and other empirical research designs to study the effectiveness of universal design have also been conducted. Consistently, researchers (i.e., Dolan, Hall, Banerjee, Chun, \& Strangman, 2005; Moon, Utschig, Todd, \& Bozzorg, 2012; Pace \& Schwartz, 2008; Roberts et al., 2011) have found implementation of UDL or UDI, whether for testing or for classroom instruction, to improve learning and more accurately assess student knowledge. The implementation of UDL also has been found to be effective for students without disabilities (Pace \& Schwartz, 2008).

Universal design incorporates various modalities to learning, such as the use of technology, which has been shown to be an effective accessibility tool (Castleberry \& Evers, 2010; Coyne, Pisha, Dalton, Zeph, \& Smith, 2012; Pace \& Schwartz, 2008; Rao \& Tanners, 2011), and best teaching strategies to enhance student learning based on contextual need. Universal design strategies allow for flexibility in instruction. Examples of universal design strategies include using a variety of instructional methods, such as guest speakers, interactive activities, discussions, in addition to traditional lectures, as well as providing feedback, having clear expectations, following syllabi closely, and using various assessment methods. 
Izzo et al. (2008) evaluated faculty perceptions of UDL. They found that many faculty were unfamiliar with UDL and needed training. Web-based training was implemented based on this finding. After training, faculty reported they were more comfortable in meeting the needs of students with disabilities. This implies that training on the methods of UDL and increasing familiarity with students with disabilities would likely improve faculty comfort with students with disabilities (Eilola et al., 2011; Moon et al., 2012; Schelly et al., 2011). In an evaluation of best practices and UDI, Madaus, Scott, and McGuire (2003a) found that faculty members who were designated as University Teaching Fellows, the highest honours given to faculty at one university, had teaching methods that were similar to the principles of UDI. These included setting high expectations, student engagement, clear expectations, and being approachable.

Thus, UDI or UDL can be applied in higher education to allow for an inclusive educational environment for students with disabilities. Students with disabilities are often excluded from curriculum and class materials, generally not due to intentional discrimination but through mishandling student concerns and lack of familiarity (Gaal \& Jones, 2003; Green, 2009). This is likely due to a lack of knowledge of how to properly include these students through an understanding of appropriate accommodations and faculty choices in instruction that create barriers to education for students with disabilities (Burgstahler \& Moore, 2009; Harrison, 2006; Leyser \& Greenberger, 2008). This, along with faculty attitudes, can lead to exclusion of students with disabilities and cause inequitable access to education.

\section{Current Study}

At the time this study was conducted, the university where the study took place did not require UDI or UDL as part of instruction. Initiatives were in place to introduce the concept to faculty and various departments on campus. An instruction committee was charged with developing recommendations, policy, and faculty training on universal design. This study is an important initial step in the implementation of universal design in the higher education classroom. Recognizing faculty perspectives on universal design, their familiarity in working with students with disabilities, and their use of instructional methods serve as valuable information in determining gaps in knowledge and where faculty training is needed. However, what is unique about this study is the evaluation of UDI and UDL as a single framework by interlacing their principles. UDI provides focus on the environment while UDL focuses on the learner. This article refers to their combined principles simply as universal design.

The purposes of this study were to assess if faculty were incorporating universal design into their curriculum and evaluate their attitudes toward students with disabilities. The findings from this study can help to determine if gaps in faculty understanding exist about universal design and how to include students with disabilities into curriculum. The research questions included (a) What are the current faculty teaching practices and are they incorporating principles of universal design? and (b) What attitudes do faculty hold about students with disabilities and accommodations they need?

\section{Method}

This quantitative study surveyed the practices and attitudes of faculty members from October 2011 through March 2012. The setting of this study was an urban four-year institution of higher education (IHE) in southern California. The community was culturally diverse, where half of the faculty population were culturally diverse. 


\section{Recruitment of Participants and Data Collection Procedures}

According to the most recent available data, the IHE is comprised of 1,292 instructionallyrelated personnel including faculty, librarians, coaches, and academic student employees. Of the instructionally-related personnel, 510 were full-time faculty, but only 485 faculty received emails due to missing emails from email lists and returned emails.

Faculty members from the six colleges of the IHE were sent emails requesting their participation in completing a survey: Arts and Letters; Business and Economics; Engineering, Computer Science, and Technology; Education; Health and Human Services; and Natural and Social Sciences. To encourage response, emails were sent out by the Deans of each college using their email lists. At least two emails were sent to faculty members separated by 3 months. The recruitment emails included both a link to a web format of the survey and an electronic Word format of the survey attached to the email. If faculty submitted using the Word format, they were to print out the survey as a hard copy, complete it, and submit it anonymously to the College of Education office. The first author also made a short presentation at faculty meetings and requested that faculty members respond to the survey. The majority of surveys were collected from an online web survey; others were submitted through hardcopy. All surveys were anonymous.

\section{Survey Instrument}

To answer the research questions, we created a survey based on existing surveys and interview protocols from prior studies discussed in the literature review with the addition of questions about universal design and instructional methods used. This survey evaluated faculty familiarity and perceptions of students with disabilities and universal design. Most questions included a Likert scale. The format was based on a survey developed by Izzo et al. (2008). Survey items included demographic questions as well questions about faculty perception and familiarity with students with disabilities (see Appendix). Other questions included familiarity with disability in general and the concept of universal design in the education setting. Questions related to the principles of UDI and UDL were created by the first author and incorporated into the survey; some questions represented strategies of UDI principles, others UDL principles. Questions from Madaus et al. (2003a) were also incorporated to determine if faculty were incorporating best practice teaching methods, which are similar to principles of universal design. Survey items were developed to assess attitudes of faculty and their willingness to accommodate students with disabilities, along with an area for additional comments at the end of the survey. The survey was validated using a "think aloud" approach, where test takers gave feedback to the survey taken and explained what they thought each question meant and why they answered items the way they did (Cohen, Swerdlik, \& Sturman, 2012; Mullens \& Kasprzyk, 1996).

\section{Data Analysis}

We categorized and scored faculty survey responses, and applied descriptive statistics to the data. Data analysis included analysis of variance (ANOVA) to determine if the means of two or more groups were different. Using this method, trends and comparisons were made. We considered $p<.05$ to be statistically significant. We used one-way ANOVA to compare means of the independent groups for the faculty survey ratings as opposed to multiple two-sample $t$ tests, which can increase the chance of Type I error (Field, 2009). We used SPSS 18 for all analyses. Faculty rated statements based on the level of agreement on a Likert scale $(1=$ strongly disagree to $5=$ strongly agree $)$ for attitude items, and frequency of use of instruction/UDL methods $(1=$ 
not often to 3 = frequently used; see Appendix). Comparisons were made on the mean frequency of use ratings for instruction items and the mean agreement ratings for attitude items for all faculty and also stratified by their demographic characteristics. We also compared use of instructional methods and faculty attitude items by faculty familiarity with disabilities, prior experience with studies with disabilities, and familiarity with the concept of universal design.

\section{Results}

Of the 485 total tenured and tenure-track full-time faculty members who were sent emails, 14 were undeliverable. Eighty-one surveys were returned, of which 8 were incomplete and not included in the analysis, leaving 73 completed surveys with a response rate of $15.5 \%$. Response rates by college were as follows: 6.1\% (7/114) for Arts and Letters; 17.4\% (12/69) for Education; 29.8\% (42/141) for Natural and Social Sciences; 7.5\% (3/40) for Engineering, Computer Science, and Technology; 3.5\% (3/40) for Business and Economics; and 8.0\% (4/50) for Health and Human Services. Of the 73 completed surveys, all faculty members answered the non-Likert scale demographic items. Five (6.8\%) surveys had one Likert scale item not rated; four (5.6\%) surveys had three or more Likert scale items not rated.

\section{Demographics}

Of the 73 faculty members who completed the survey, over half $(57.5 \%)$ were full professors, and the remainder were associate $(23.3 \%)$ and assistant $(19.2 \%)$ professors. The majority taught in the College of Natural and Social Sciences $(57.5 \%)$ followed by the College of Education (16.4\%). Most faculty members $(80.8 \%)$ taught both undergraduate and graduate level students. The average class size taught was 42 (range from 1 to 180) students, of which an average of 3 (range 0 to 30) students of whom faculty were aware had disabilities in their classes over the past year. Faculty had been teaching for an average of 18.3 years. More faculty members were women $(58.9 \%)$ and approximately half $(50.7 \%)$ were 50 years and older. Over half (56.2\%) either reported having a disability or had a personal experience with disability (e.g., having a family member with a disability). More faculty members $(56.2 \%)$ noted having positive experiences with students with disabilities, while $2.7 \%$ had negative experiences. The majority of faculty members $(71.2 \%)$ were unfamiliar with the concept of universal design.

\section{Instructional Methods and Universal Design}

The frequency of use of instructional methods and universal design principles varied. Overall, faculty used a variety of methods and practices that were similar to or represented examples of the universal design principles. The Appendix lists the survey items and corresponding UDI and UDL principles. Some items are not universal design principles themselves, but rather are examples of strategies to implement some of the principles. Providing a variety of methods for engagement (UDL) can include lectures, guest speaker, brainstorming, videos, class discussion, small group discussion, case studies, hands-on/interactive activities, and critical thinking activities. They can also be examples of providing multiple methods of representing (UDL) material, using visual, auditory, and textual information for students to learn. These also represent examples of how to implement UDI principles of flexibility in use and allowing for a community of learners. The instruction methods/strategies used most frequently were following their syllabus closely $(M=2.9)$, being available outside of class $(M=3.0)$, providing feedback $(M=2.8)$, observing communication among students $(M=2.8)$, using lectures $(M=2.8)$, and including 
class discussions into their classes $(M=2.7)$. The methods used less often were guest lectures $(M$ $=1.4)$, videos $(M=1.9)$, and giving students a choice in assessment methods $(M=1.5)$.

When data were analyzed in terms of the colleges with which faculty were affiliated, there were some differences noted in use of instructional methods and incorporation of universal design principles. Faculty in Health and Human Services used four methods less frequently than other faculty: guest lectures, small class discussion, hands on/interactive activities, and having students turn in individual components of a paper/project for feedback for later integration; however, only guest lectures $(M=1.0, p=.03)$ and small class discussion $(M=1.8, p=.04)$ were used significantly less. Faculty in Arts and Letters used critical thinking $(M=2.4, p=.19 n s)$ and outline/lecture notes prior to class $(M=1.4, p=.24 n s)$ less often than other faculty. Faculty members in the College of Education gave students a choice in assessment methods $(M=2.1, p$ $=.08$, trend level) more often than other faculty.

When we analyzed data by age, professorial rank (assistant, associate, full), number of years taught at the college level, class size, gender, and personal experience with a disability (having a disability or having a family member with a disability), there were no significant differences in the frequency of using the instructional methods or incorporation of universal design principles. Faculty who reported no familiarity with the concept of universal design used case studies $(M=2.0, p=.11 n s)$ and provided outline/lecture notes prior to class $(M=2.0, p=.04)$ less often than faculty who were familiar. Faculty who had no known or identified students with disabilities in their classes over the past year used class discussion $(M=2.3, p=.04)$ and case studies $(M=1.7, p=.15 n s)$, and allowed students to turn in individual project components for feedback prior to being graded $(M=1.6, p=.41 n s$; Table 1$)$ less often than other faculty. Faculty who had a negative experience with students with disabilities gave students a choice in assessment less than other faculty $(M=1.0, p=.007$; Table 2).

Table 1

Instructional Methods:

Frequency of Use by Number of Students with Disabilities Professors had in the Past Year

\begin{tabular}{|c|c|c|c|c|c|}
\hline & $\begin{array}{l}\text { None } \\
n=8\end{array}$ & $\begin{aligned} & \leq 3 \\
n & =31\end{aligned}$ & $\begin{array}{c}>3 \\
n=29\end{array}$ & $\begin{array}{c}\text { Not } \\
\text { reported } \\
n=4\end{array}$ & $p$ \\
\hline Lecture & 2.9 & 2.6 & 2.9 & 2.8 & - \\
\hline Guest lecture & 1.2 & 1.5 & 1.3 & 1.8 & - \\
\hline Brainstorming & 1.7 & 2.1 & 2.0 & 1.8 & - \\
\hline Videos & 2.1 & 1.9 & 1.8 & 2.3 & - \\
\hline Class discussion & 2.3 & 2.8 & 2.8 & 3.0 & .04 \\
\hline Small class discussion & 2.0 & 2.4 & 2.3 & 2.0 & - \\
\hline Case studies & 1.7 & 2.2 & 2.2 & 2.3 & - \\
\hline Hands on/Interactive activities & 2.3 & 2.3 & 2.4 & 2.0 & - \\
\hline Critical thinking & 2.8 & 2.7 & 2.7 & 2.5 & - \\
\hline Other & 2.0 & 2.1 & 1.7 & - & - \\
\hline Choice in assessment & 1.3 & 1.6 & 1.2 & 2.0 & - \\
\hline Follow syllabus & 3.0 & 2.8 & 3.0 & 3.0 & - \\
\hline Individual components & 1.6 & 2.1 & 2.1 & 1.8 & - \\
\hline Outline/Class notes prior class & 2.3 & 2.2 & 2.2 & 2.0 & - \\
\hline Classroom arrangement & 2.9 & 2.4 & 2.2 & 3.0 & - \\
\hline Provide feedback & 2.9 & 2.8 & 2.9 & 3.0 & - \\
\hline Communication among students observed & 2.6 & 2.8 & 2.8 & 3.0 & - \\
\hline Available outside of class & 3.0 & 2.9 & 3.0 & 3.0 & - \\
\hline
\end{tabular}

Note. Likert scale: 1 = not often, 2 = sometimes, 3 = often used; ANOVA was used to compare means of the groups for each item, except Not reported group was not included in analysis. 
Table 2

Instructional Methods:

Frequency of Use by Experience Professors had with Students with Disabilities

\begin{tabular}{|c|c|c|c|c|c|c|}
\hline & $\begin{array}{c}\text { Negative } \\
n=2\end{array}$ & $\begin{array}{c}\text { Neutral } \\
n=26\end{array}$ & $\begin{array}{c}\text { Positive } \\
n=41\end{array}$ & $\begin{array}{c}\text { No } \\
\text { experience } \\
n=2\end{array}$ & $\begin{array}{l}\text { Not } \\
\text { reported } \\
n=2\end{array}$ & $p$ \\
\hline Lecture & 3.0 & 2.7 & 2.8 & 3.0 & 2.5 & - \\
\hline Guest lecture & 1.0 & 1.5 & 1.4 & 1.0 & 2.0 & - \\
\hline Brainstorming & 1.5 & 2.0 & 2.0 & 3.0 & 2.0 & - \\
\hline Videos & 2.5 & 1.8 & 2.0 & 3.0 & 2.0 & - \\
\hline Class discussion & 3.0 & 2.6 & 2.8 & 2.5 & 3.0 & - \\
\hline Small class discussion & 2.0 & 2.4 & 2.3 & 2.5 & 2.5 & - \\
\hline Case studies & 2.0 & 2.2 & 2.1 & 3.0 & 2.5 & - \\
\hline Hands on/Interactive activities & 1.0 & 2.4 & 2.2 & 3.0 & 3.0 & .03 \\
\hline Critical thinking & 2.5 & 2.8 & 2.7 & 3.0 & 3.0 & - \\
\hline Other & 1.0 & 2.2 & 1.8 & 3.0 & 1.0 & - \\
\hline Choice in assessment & 1.0 & 1.3 & 1.5 & 3.0 & 3.0 & .01 \\
\hline Follow syllabus & 3.0 & 2.8 & 3.0 & 3.0 & 3.0 & - \\
\hline Individual components & 1.5 & 2.1 & 2.0 & 1.5 & 3.0 & - \\
\hline Outline/Class notes prior class & 3.0 & 2.5 & 2.0 & 2.0 & 2.0 & - \\
\hline Classroom arrangement & 3.0 & 2.4 & 2.4 & 2.5 & 3.0 & - \\
\hline Provide feedback & 3.0 & 2.8 & 2.9 & 3.0 & 3.0 & - \\
\hline Communication among students observed & 2.5 & 2.8 & 2.7 & 2.5 & 3.0 & - \\
\hline Available outside of class & 3.0 & 2.9 & 3.0 & 3.0 & 3.0 & - \\
\hline
\end{tabular}

\section{Attitudes and Willingness to Accommodate Students with Disabilities}

The data regarding attitudes of faculty about students with disabilities and their willingness to provide accommodations for them were mostly positive. Most faculty agreed with statements about willingness to accommodate and were comfortable with students with disabilities. For the survey item "Students with disabilities are better able to learn if faculty use a variety of teaching methods in their classes," the average rating was 3.7. This rating trended toward agreeing, but at a low level of agreement. This indicates faculty are not aware that using a variety of methods do help students with disabilities learn. Most faculty disagreed with statements that were negative toward students with disabilities.

Although the College of Engineering, Computer Science, and Technology faculty had lower agreement ratings to statements regarding comfort with students with disabilities (using assistive technology, $M=3.7, p=0.13 n s$, and talking about disability, $M=3.7, p=0.11 n s$ ), there were no significant differences when analyzed by college. Their responses were close to neutral (lower) compared to other faculty. On the Likert scale, they were more neutral or had higher agreement ratings to negative statements, and thus more negative attitudes, regarding students with disabilities compared to other faculty, but not significantly higher.

When data were analyzed by faculty age, gender, number of years taught at the college level, professorial rank, and class size, there were no significant differences found in attitudes and willingness to accommodate students with disabilities. Familiarity with accommodations used was highest with faculty who taught more than three students with disabilities in the past year in their classes $(M=4.3)$, followed by faculty with three or less $(M=3.7)$, and lowest with faculty who had no students with disabilities $(M=3.3), p=.002$ (Table 3$)$. Faculty who had no students with disabilities in the past year were neutral to the negative statements about students with disabilities: "Students with disabilities tend to receive unfair advantages" and "Students 
with disabilities are more difficult to work with," but they were not significant. Faculty who did not have personal experience with disability (having a disability or having a family member with a disability), compared to those who did, rated higher in agreement to the negative statements "Students with disabilities get unfair advantages" $(p=.009)$ and "Students with disabilities are more difficult to work with" ( $p=.04$; Table 4$)$. Faculty who rated themselves as being very familiar with the concept of universal design strongly disagreed with negative statements regarding students with disabilities $(M=1.0$ to 1.3$)$, but not significantly more than other faculty.

We also analyzed data by the type of experience faculty had with students with disabilities (negative, positive, neither, no experience). Compared to other faculty, faculty with no experience had the least familiarity with accommodations used as demonstrated by their disagreement with the statement "Familiar with types of accommodations that may be used" $(M=2.0, p=$ .007). Faculty with negative experiences had the lowest agreement to the statement "Feel comfortable when the student uses assistive technology" $(M=3.5, p=.03)$. They tended to agree with the statements "Students with disabilities tend to get unfair advantages" $(M=3.5, p=.07$, trend level) and "Students with disabilities are more difficult to work with than other students" $(M=3.5, p=.06$, trend level).

\section{Comments Provided by Faculty}

Comments made were quite variable and gave more insight into faculty perspectives and attitudes as they relate to instruction and students with disabilities. Some faculty understood that all students, not just those with disabilities, could benefit and learn from a variety of teaching methods. Other faculty noted that although students with disabilities can be more challenging, they are not difficult to work with and viewed them as having unique styles of learning. One faculty member seemed to incorporate some universal design principles into his or her teaching when stating, "Because I use a variety of assessing methods, students with disabilities in the past

Table 3

Familiarity, Attitudes, and Willingness to Accommodate by Number of Students with Disabilities Professors had in the Past Year

\begin{tabular}{|c|c|c|c|c|c|}
\hline & $\begin{array}{l}\text { None } \\
n=8\end{array}$ & $\begin{array}{c}\leq 3 \\
n=31\end{array}$ & $\begin{array}{c}>3 \\
n=29\end{array}$ & $\begin{array}{l}\text { Not } \\
\text { reported } \\
n=4\end{array}$ & $p$ \\
\hline Familiar with types of accommodations that may be used & 3.3 & 3.7 & 4.3 & 4.8 & .00 \\
\hline Willing to provide accommodations & 4.6 & 4.6 & 4.8 & 5.0 & - \\
\hline $\begin{array}{l}\text { Willing to adapt instructional strategies and course materials to } \\
\text { meet student's needs }\end{array}$ & 3.9 & 4.2 & 4.2 & 5.0 & - \\
\hline $\begin{array}{l}\text { Have the same expectations from students with disabilities as } \\
\text { from other students }\end{array}$ & 4.5 & 4.2 & 4.3 & 4.8 & - \\
\hline $\begin{array}{l}\text { Feel comfortable when the student uses assistive technology } \\
\text { (such as a tape recorder or computer in my classroom) }\end{array}$ & 4.5 & 4.6 & 4.7 & 4.8 & - \\
\hline $\begin{array}{l}\text { Feel comfortable when the student talks to me about his/her } \\
\text { disability }\end{array}$ & 4.8 & 4.5 & 4.7 & 5.0 & - \\
\hline $\begin{array}{l}\text { Students with disabilities are better able to learn if faculty use a } \\
\text { variety of teaching methods in their classes }\end{array}$ & 3.5 & 3.6 & 3.8 & 3.8 & - \\
\hline Students with disabilities tend to get unfair advantages & 2.8 & 2.2 & 2.4 & 1.5 & - \\
\hline $\begin{array}{l}\text { Students with disabilities should be enrolled in a class other than } \\
\text { mine }\end{array}$ & 1.6 & 1.6 & 1.6 & 1.0 & - \\
\hline $\begin{array}{l}\text { Students with disabilities are more difficult to work with than } \\
\text { other students }\end{array}$ & 2.6 & 2.1 & 2.2 & 1.5 & - \\
\hline
\end{tabular}


Table 4

Familiarity, Attitudes, and Willingness to Accommodate by Experience Professors had with Students with Disabilities

\begin{tabular}{|c|c|c|c|c|c|c|}
\hline & $\begin{array}{l}\text { Negative } \\
n=2\end{array}$ & $\begin{array}{l}\text { Neutral } \\
n=26\end{array}$ & $\begin{array}{c}\text { Positive } \\
n=41\end{array}$ & $\begin{array}{c}\text { No } \\
\text { experience } \\
n=2\end{array}$ & $\begin{array}{l}\text { Not } \\
\text { reported } \\
n=2\end{array}$ & $p$ \\
\hline $\begin{array}{l}\text { Familiar with types of accommodations that } \\
\text { may be used }\end{array}$ & 3.5 & 4.0 & 4.0 & 2.0 & 5.0 & .01 \\
\hline $\begin{array}{l}\text { Willing to provide accommodations } \\
\text { Willing to adapt instructional strategies and }\end{array}$ & 4.5 & 4.6 & 4.8 & 5.0 & 5.0 & - \\
\hline course materials to meet student's needs & 3.5 & 4.1 & 4.3 & 3.5 & 5.0 & - \\
\hline $\begin{array}{l}\text { Have the same expectations from students } \\
\text { with disabilities as from other students }\end{array}$ & 4.5 & 4.3 & 4.2 & 4.5 & 5.0 & - \\
\hline $\begin{array}{l}\text { Feel comfortable when the student uses assis- } \\
\text { tive technology (such as a tape recorder or } \\
\text { computer in my classroom) }\end{array}$ & 3.5 & 4.6 & 4.7 & 4.5 & 5.0 & .03 \\
\hline $\begin{array}{l}\text { Feel comfortable when the student talks to me } \\
\text { about his/her disability }\end{array}$ & 4.5 & 4.6 & 4.6 & 4.5 & 5.0 & - \\
\hline $\begin{array}{l}\text { Students with disabilities are better able to } \\
\text { learn if faculty use a variety of teaching } \\
\text { methods in their classes }\end{array}$ & 3.5 & 3.5 & 3.8 & 4.0 & 3.0 & - \\
\hline $\begin{array}{l}\text { Students with disabilities tend to get unfair } \\
\text { advantages }\end{array}$ & 3.5 & 2.6 & 2.2 & 2.5 & 1.0 & .07 \\
\hline $\begin{array}{l}\text { Students with disabilities should be enrolled in } \\
\text { a class other than mine } \\
\text { Students with disabilities are more difficult to }\end{array}$ & 1.5 & 1.7 & 1.5 & 1.5 & 1.0 & - \\
\hline work with than other students & 3.5 & 2.4 & 2.0 & 2.5 & 1.0 & .06 \\
\hline
\end{tabular}

have not used the OSD (Office for Students with Disabilities) office as much, preferring to get time extensions directly from me for their online assignments."

Many of the comments related to attitudes that faculty had toward students with disabilities varied. Some were positive, while others were negative. Some professors noted that students with disabilities in their classes enrich the educational experience, while other professors felt that some students acted "entitled" or they wished the students had supplied sufficient notice ahead of time regarding the need for accommodations. Others noted that some accommodations can be perceived as unfair for what they considered a less severe diagnosis, such as a learning disability, while other faculty members noted that some students gain unfair advantages. Attitudes varied depending on prior experiences and familiarity.

As noted, providing accommodations was a concern faculty expressed in the comments section. Faculty members had assumptions, some of which were not based on fact, and thus further demonstrate the need for education and training of faculty on the accommodation process and why some students with disabilities may need certain accommodations. One assumption made by a faculty member related to the proctoring of examinations for students with disabilities. This is an area where the faculty member felt "unfair advantages" can occur, stating,

Disabled students taking an exam outside of the classroom get unfair examination arrangements when the timing of questions/answers is one of the assessment factors (i.e., it is a factor that determines the grade); however, it is acceptable, and increased time can be provided in the classroom, not necessarily in a separate facility....With smart phones (or other easily concealed technology) unchecked, a student who takes an exam without eye control of a proctor can use Web sources to self-assist with examination questions or can photograph the questions to disseminate to other students who will take the exam later....Some exams are online on a campus computer in a classroom...and the instructor in a class- 
room must prevent students from using other Web sites - that is easily done in the classroom, but may not be exercised in the disability examination rooms.

Based on comments like these, to help alleviate concerns and change attitudes, faculty need to be informed of the actual proctoring process of students with disabilities who take exams outside the classroom. One professor who had negative experiences with students with disabilities stated,

Most of the disabled students I have are, in my opinion, trying to 'work the system.' I know that two are ex-convicts and professional liars. They claim they need extra time, etc., but I see no evidence of any real problems. Of course, I have no choice but to go along with their charade.

This comment is another example of assumptions that some faculty have about students with disabilities, especially with the need to accommodate students with hidden disabilities, an area where education of faculty is needed. Other comments made were more descriptive about faculty needs. One professor noted,

I believe most faculty members in my discipline are not well informed in different types of accommodations, different instructional strategies or technology, etc. I will be very interested in learning about how many universities are currently training their faculty members.

Another faculty member stated,

I don't feel the OSD provides me with any information on what I need to do to assist students in my class with disabilities, and when they receive accommodations, I am not made very aware of what those accommodations are or why they are necessary.

\section{Discussion}

We surveyed faculty members to evaluate (a) whether or not they were already incorporating some of the principles of universal design in their instruction by evaluating their current teaching methods and (b) their attitudes toward students with disabilities.

\section{Instructional and Universal Design Methods Used by Faculty}

Faculty reported using a variety of instructional methods. Most faculty reported using each method (e.g., class discussion, interactive activities, lectures) at least somewhat often. There were only two methods faculty reported using less frequently-giving students a choice in assessment methods and having guest lectures. In following some of the principles of universal design, some faculty were already incorporating practices based on these methods, such as providing feedback, being available outside of class, and following their syllabus closely. Because the majority of faculty members were unfamiliar with the concept of universal design, which requires upfront planning, it could be that these incorporations of various teachings methods were coincidental. Some faculty used a combination of instructional methods to present information that is representative of universal design principles. However, methods used only somewhat frequently were providing a lecture outline prior to class and having students turn in individual components of a project for feedback for later integration into the final project for grading.

Faculty who had negative experiences with students with disabilities rated more instructional items lower in use than other faculty. Some of these items were significantly lower, such as hands on/interactive activities and choice in assessment. However, having a negative experi- 
ence with students with disabilities may be associated with the amount of effort faculty may put into providing a variety of instructional methods to engage and be inclusive of all students.

Interestingly, just being familiar or even very familiar with the concept of universal design did not have a significant difference on the frequency of use of a variety of instructional methods or incorporation of universal design principles by faculty, overall. The exception was with faculty who were somewhat or very familiar with universal design who provided lecture outlines prior to class significantly more when compared to faculty who were not familiar with universal design. Faculty who taught students with disabilities in the past year used a variety of universal design instructional methods more frequently than faculty who did not have any students with disabilities, such as using more class discussion. This may be related to their familiarity in working with students with disabilities, and thus being more likely to employ various types of instructional methods that are beneficial for all students, especially for students with disabilities.

\section{Comparing Faculty Use of Instructional/Universal Design Methods with Student Perspectives}

Faculty use of instructional methods and universal design principles can be compared to perspectives of students with and without disabilities and their rating on what they feel are useful instructional methods for learning (Black, Weinberg, \& Brodwin, 2013). In the current study, faculty used lectures most frequently, whereas Black et al. (2013) found that students rated lectures only slightly more than somewhat useful. Lectures were also rated lowest by students with disabilities and guest speakers were rated lowest by students without disabilities. Faculty only used case studies somewhat frequently; however, students rated case studies fairly high in usefulness. Other instructional methods were rated similar between student perspective on usefulness and faculty rating on frequency of use.

Concerning incorporation of universal design principles, student perspectives can also be compared to faculty ratings. Faculty rated giving students a choice in assessment methods fairly low in frequency, whereas Black et al. (2013) found that students rated choice in assessment methods high in usefulness. Other items used infrequently by faculty but rated high in usefulness by students included turning in individual components of an assignment for feedback for later integration into a graded assignment and having a lecture outline prior to class. Other principles of universal design that faculty were already incorporating into their instruction as being rated high in frequency by faculty and high in usefulness by students included providing feedback, being available outside of class, observing communication among students, and faculty following their syllabi closely, which helps provide students with clear expectations. This is in agreement with other studies that noted the importance of faculty incorporation of universal design principles and best practices similar to universal design (Madaus et al., 2003b; Schelly et al., 2011).

\section{Attitudes and Willingness to Accommodate Students with Disabilities}

Faculty attitudes toward students with disabilities were mainly positive. Most faculty members were willing to accommodate students with disabilities. There were some survey items regarding students with disabilities where faculty ratings were more neutral (e.g., "Students with disabilities are better able to learn if faculty use a variety of teaching methods in their classes"). The neutral responses indicate that faculty were not aware that using a variety of methods has been found to help students learn. For another survey item, "Students with disabilities tend to get unfair advantages," faculty, although they tended to disagree with this statement, did rate it 
closer to neutral. Faculty also disagreed with the statement "Students with disabilities are more difficult to work with than other students," although their disagreement was not strong.

Faculty were overall neutral in agreement to negative statements ("Students with disabilities tend to get unfair advantages" and "Students with disabilities are more difficult to work with than other students") about students with disabilities. However, when analyzed by having personal experience with disability (having a disability or a family member with a disability), faculty who did not have personal experience were significantly higher in agreeing with negative statements than faculty with personal experience. Their agreement with the negative statements above are likely related to lack of familiarity with students with disabilities, or disabilities in general since they lacked personal experience, and the accommodations those with disabilities use. Faculty who had not taught students with disabilities in the past year were also significantly less familiar with the types of accommodations used by students compared to other faculty. This too relates to familiarity with students with disabilities, accommodations, the accommodation process, and how to work with students with disabilities. Thus, a major barrier for students with disabilities in accommodations is faculty attitudes; this study confirms findings reported in the literature (Burgstahler, Duclos, \& Turcotte, 2000; Kurth \& Mellard, 2006). Murray, Lombardi, Wren, and Keys (2009) found that faculty who received prior training in disability-related workshops or courses reported the most positive attitudes toward students with disabilities and were more willing to accommodate, invest in the students, and be fair and sensitive.

A major theme that faculty expressed in their comments was related to accommodations, mainly the lack of familiarity they had with this concept. There were several assumptions made by faculty about accommodations, especially with regard to examinations, which may indicate they have not been provided with adequate training. One assumption was that proctoring exams from OSD was not as diligent and students can cheat by using their smart phones or going online. Based on comments like this, it appears that faculty need to be informed of the actual proctoring process of students with disabilities who take exams outside the classroom to help alleviate these concerns. This demonstrates how little faculty are informed about the process of accommodations and the safeguards to uphold exam integrity. Faculty also noted that they lacked training and admitted they are uninformed as to the accommodations that are available and why some accommodations are used. This may explain some of the comments made and assumptions faculty expressed in the surveys.

The lack of training in working with students with disabilities is not unique to this university. Cook, Rumrill, and Tankersley (2009) evaluated the understanding of 307 faculty members within an eight-campus university system. Faculty were asked about their understanding of legal knowledge of disability-related legislation (e.g., Rehabilitation Act or Americans with Disabilities Act), accommodations policy of the university, willingness to accommodate, universal design, disability characteristics, and etiquette (stereotyping students with disabilities). The authors found a discrepancy between what faculty members viewed as being important and what action they were taking in working with students with disabilities. Many felt that policies and disability etiquette were important and were addressed. However, faculty felt that laws related to these issues, universal design, and disability characteristics were not satisfactorily attended to at their universities, demonstrating that more training is necessary.

\section{Limitations}

A limitation of this study was the response rate of $15.5 \%$. However, the study did include faculty from all the colleges. Faculty completed surveys anonymously, which is a strength of the 
study, increasing the likelihood of obtaining more honest responses than an interview. However, because of the anonymous nature of the surveys, follow up on responses for more information was not possible. As noted, most faculty were unfamiliar with universal design concepts; thus, use of principles or incorporation of teaching methods based on those principles may have been coincidental and not necessarily that faculty intended to incorporate universal design principles.

\section{Recommendations}

It is imperative that faculty incorporate principles and guidelines for universal design in their instruction to help create a more inclusive educational environment for students with disabilities (CAST, 2013a; McGuire \& Scott, 2006b; McGuire et al., 2003; Pliner \& Johnson, 2004; Roberts et al., 2011; Schelly et al., 2011). The following are ways in which faculty can incorporate universal design: (a) present instructional materials in a variety of ways to incorporate students with different learning styles (e.g., text, visual, and audio); (b) engage students using a variety of formats (e.g., videos, lectures, class discussion, and interactive activities); (c) allow students to express their knowledge through several means of assessment to encompass different learning styles (e.g., papers, presentations, or exams); (d) provide feedback; (e) have clear expectations (e.g., following syllabi closely and excluding confusing language); and (f) create a welcoming environment that promotes communication between students and faculty and among students. However, faculty also require training in the principles of universal design so they can be comfortable in properly integrating universal design into their instruction to decrease barriers. Additional faculty training on disability awareness and related issues, as well as on accommodations and the accommodation process, particularly for hidden disabilities, would help decrease attitudinal barriers that impede education.

\section{Conclusion}

This study revealed that faculty members do use a variety of instructional methods; yet, some use more methods than others do. A few faculty members were already incorporating universal design methods, but there is more that can be improved. Faculty attitudes are a barrier, which often stemmed from lack of familiarity and training. Provision of accommodations was a major concern for faculty in that many were unfamiliar with accommodations and the reasons they are necessary. Overcoming attitudinal barriers and improving awareness through training for faculty on using universal design methods for instruction would create a more inclusive environment for students with disabilities.

\section{References}

Black, R. D., Weinberg, L. A., \& Brodwin, M. G. (2013). Universal design for learning: Perspectives of students with disabilities in higher education [unpublished manuscript].

Brown, K. S., Welsh, L. A., Hill, K. H., \& Cipko, J. P. (2008). The efficacy of embedding special education instruction in teacher preparation programs in the United States. Teaching and Teacher Education: An International Journal of Research and Studies, 24(8), 2087-2094. doi:10.1016/j.tate.2008.02.013

Burgstahler, S. (2012). Universal design: Process, principles, and applications. DO-IT (Disabilities, Opportunities, Internetworking, and Technology). Retrieved from http://www.washington.edu/doit /Brochures/PDF/ud.pdf

Burgstahler, S., Duclos, R., \& Turcotte, M. (2000). Preliminary findings: Faculty, teaching assistant, and student perceptions regarding accommodating students with disabilities in postsecondary environments. DO-IT (Disabilities, Opportunities, Internetworking, and Technology). Retrieved from http://staff.washington.edu/sherylb/prelim.html 
Burgstahler, S., \& Moore, E. (2009). Making student services welcoming and accessible through accommodations and universal design. Journal of Postsecondary Education and Disability, 21(3), 155-174. Retrieved from http://www.ahead.org/publications/jped

CAST. (2013a). About UDL. Retrieved from http://www.cast.org/udl/index.html

CAST. (2013b). Research and development. Retrieved from http://www.cast.org/research/index.html

Castleberry, G. T., \& Evers, R. B. (2010). Incorporate technology into the modern language classroom. Intervention in School and Clinic, 45(3), 201-205. doi:10.1177/1053451209349535

Center for Universal Design. (1997). The principles of universal design, version 2.0. Raleigh, NC: North Carolina State University.

Center for Universal Design. (2008). Universal design principles. Retrieved from http://www.ncsu.edu/www /ncsu/design/sod5/cud/about_ud/udprinciples.htm

Cohen, R. J., Swerdlik, M. E., \& Sturman, E. (2012). Psychological testing and assessment: An introduction to tests and measurement (6th ed.). Boston, MA: McGraw-Hill.

Cook, L., Rumrill, P. D., \& Tankersley, M. (2009). Priorities and understanding of faculty members regarding college students with disabilities. International Journal of Teaching and Learning in Higher Education, 21, 84-96. Retrieved from http://www.isetl.org/ijtlhe/pdf/IJTLHE567.pdf

Coyne, P., Pisha, B., Dalton, B., Zeph, L. A., \& Smith, N. C. (2012). Literacy by design: A universal design for learning approach for students with significant intellectual disabilities. Remedial and Special Education, 33(3), 162-172. doi: 10.1177/0741932510381651

Dolan, R. P., Hall, T. E., Banerjee, M., Chun, E., \& Strangman, N. (2005). Applying principles of universal design to test delivery: The effect of computer-based read-aloud on test performance of high school students with learning disabilities. Journal of Technology, Learning, and Assessment, 3(7), 1-33. Retrieved from http://ejournals.bc.edu/ojs/index.php/jtla/article/view/1660

Eilola, C., Fishman, K., Greenburg, A., Moore, C. D., Schrijver, A., \& Totino, J. (2011). Success with ACCESS: Use of community-based participatory research for implementation. Journal of Postsecondary Education and Disability, 24(1), 61-65. Retrieved from http://www.ahead.org /publications/jped/

Embry, P. B., Parker, D. R., McGuire, J. M., \& Scott, S. S. (2005). Postsecondary disability service providers' perceptions about implementing universal design for instruction (UDI). Journal of Postsecondary Education and Disability, 18(1), 34-48. Retrieved from http://www.ahead.org/publications/jped

Field, A. (2009). Comparing several means: ANOVA. Discovering statistics using SPSS (3rd ed.). Thousand Oaks, CA: Sage.

Gaal, J., \& Jones, P. A. (2003). Disability discrimination in higher education. Journal of College and University Law, 29(2), 435-456. Retrieved from http://www3.nd.edu/ jcul/

Green, R. A. (2009). Assistive technology and academic libraries: Legal issues and problem resolution. Journal of Access Services, 6, 36-47. doi:10.1080/15367960802247809

Harris, J., Ho, T., Markle, L., \& Wessel, R. (2011). Ball State University's faculty mentorship program: Enhancing the first-year experience for students with disabilities. About Campus, 16(2), 27-29. doi:10 $.1002 / \mathrm{abc} .20058$

Harrison, E. G. (2006). Working with faculty toward universally designed instruction: The process of dynamic course design. Journal of Postsecondary Education and Disability, 19(2), 152-162. Retrieved from http://www.ahead.org/publications/jped

Humphrey, M., Woods, L., \& Huglin, L. (2012). Increasing faculty awareness of students with disabilities: A two-pronged approach. Journal of Postsecondary Education and Disability, 24(3), 255-261. Retrieved from http://www.ahead.org/publications/jped

Izzo, M. V., Murray, A., \& Novak, J. (2008). The faculty perspective on universal design for learning. Journal of Postsecondary Education and Disability, 21(2), 60-72. Retrieved from http://www.ahead.org /publications/jped

Kurth, N., \& Mellard, D. (2006). Student perceptions of the accommodation process in postsecondary education. Journal of Postsecondary Education and Disability, 19(1), 71-84. Retrieved from http://www.ahead.org/publications/jped 
Leyser, Y., \& Greenberger, L. (2008). College students with disabilities in teacher education: Faculty attitudes and practices. European Journal of Special Needs Education, 23(3), 237-251. doi:10.1080 $/ 08856250802130442$

Madaus, J. W., Scott, S. S., \& McGuire, J. M. (2003a). Addressing student diversity in the classroom: The approaches of outstanding university professors (Tech. Rep. No. 02). Center on Postsecondary Education and Disability, University of Connecticut. Retrieved from http://www.facultyware.uconn .edu/files/Tech_Report_02 faculty_interviews.pdf.

Madaus, J. W., Scott, S. S., \& McGuire, J. M. (2003b). Barriers and bridges to learning as perceived by postsecondary students with learning disabilities (Tech. Rep. No. 01). Center on Postsecondary Education and Disability, University of Connecticut. Retrieved from http://www.facultyware.uconn .edu/files/Tech_report_01_Student_Focus_Groups.pdf.

McGuire, J. M., \& Scott, S. S. (2006a). An approach for inclusive college teaching: Universal design for instruction. Learning Disabilities: A Multidisciplinary Journal, 14, 21-32. http://www.ldaamerica .org

McGuire, J. M., \& Scott, S. S. (2006b). Universal design for instruction: Extending the universal design paradigm to college instruction. Journal of Postsecondary Education and Disability, 19(2), 124-134. Retrieved from http://www.ahead.org/publications/jped

McGuire, J. M., Scott, S. S., \& Shaw, S. F. (2003). Universal design for instruction: The paradigm, its principles, and products for enhancing instructional access. Journal of Postsecondary Education and Disability, 17(1), 10-20. Retrieved from http://www.ahead.org/publications/jped

Moon, N. W., Utschig, T. T., Todd, R. L., \& Bozzorg, A. (2012). Evaluation of programmatic interventions to improve postsecondary STEM education for students with disabilities: Findings from SciTrain University. Journal of Postsecondary Education and Disability, 24(4), 331-349. Retrieved from http://www.ahead.org/publications/jped

Mullens, J. E., \& Kasprzyk, D. (1996). Using qualitative methods to validate quantitative survey instruments. Paper presented at the Meeting of the American Statistical Association, Washington, DC.

Murray, C., Lombardi, A., Wren, C. T., \& Keys, C. (2009). Associations between prior disability-focused training and disability-related attitudes and perceptions among university faculty. Learning Disability Quarterly, 32(2), 87-100. doi: 10.2307/27740359

Pace, D., \& Schwartz, D. (2008). Accessibility in post secondary education: Application of UDL to college curriculum. US-China Education Review, 5(12), 20-26. Retrieved from http://www.davidpublishing .com/show .html?6497

Pliner, S., \& Johnson, J. (2004). Historical, theoretical, and foundational principles of universal instructional design in higher education. Equity \& Excellence in Education, 37(2), 105-113. doi: 10.1080 $/ 10665680490453913$

Rao, K., \& Tanners, A. (2011). Curb cuts in cyberspace: Universal instructional design for online courses. Journal of Postsecondary Education and Disability, 24(3), 211-229. Retrieved from http://www .ahead.org /publications/jped

Roberts, K. D., Park, H. J., Brown, S., \& Cook, B. (2011). Universal design for instruction in postsecondary education: A systematic review of empirically based articles. Journal of Postsecondary Education and Disability, 24(1), 5-15. Retrieved from http://www.ahead.org/publications/jped

Schelly, C. L., Davies, P. L., \& Spooner, C. L. (2011). Student perceptions of faculty implementation of universal design for learning. Journal of Postsecondary Education and Disability, 24(1), 17-30. Retrieved from http://www.ahead.org/publications/jped

Van Laarhoven, T. R., Munk, D. D., Lynch, K., Bosma, J., \& Rouse, J. (2007). A model for preparing special and general education preservice teachers for inclusive education. Journal of Teacher Education, 58(5), 440-455. doi: 10.1177/0022487107306803

\section{Authors' Note}

Correspondence concerning this article should be addressed to R. David Black, 4351 Fountain Villas Ct, Baldwin Park, CA 91706. Email: dblack3030@gmail.com 


\section{Appendix}

\section{Survey Items: Faculty Characteristics, Disability Familiarity, and Attitudes}

\section{Faculty Characteristics}

What is your position? Assistant professor, Associate professor, or Full professor

How many years of college teaching experience do you have?

In which college do you work?

What is your Department/Division?

What class level(s) do you teach? (mark all that apply): Undergraduate, Graduate, Other

What class size do you teach? (number of students)

What is your age?

What is your gender?

Disability Familiarity

Do you have a disability?

Have you had personal or family experience with an individual who has a disability?

Approximately how many students with disabilities (who you were aware of) have you had in your classes within the last year?

Am familiar with the types of accommodations that may be used*

Students with disabilities are better able to learn if faculty use a variety of teaching methods in their classes*

Familiarity with Universal Design

How familiar are you with the term Universal Design for Learning or Instruction? Not Familiar, Familiar, or Very Familiar

\section{Attitudes*}

Am willing to provide accommodations

Am willing to adapt my instructional strategies and course materials to meet students' needs

Have the same expectations from students with disabilities as from other students

Feel comfortable when the student uses assistive technology (such as a tape recorder or computer in my classroom)

Feel comfortable when the student talks to me about his/her disability

Students with disabilities tend to get unfair advantages

Students with disabilities should be enrolled in a class other than mine

Students with disabilities are more difficult to work with than other students

${ }^{*}$ Rate level of agreement: 1 = strongly disagree, 2 = disagree, $3=$ neither agree nor disagree, $4=$ agree, $5=$ strongly agree.

\section{Survey items related to UDI or UDL principles}

\begin{tabular}{|c|c|c|}
\hline Instruction Items & UDL & UDI \\
\hline $\begin{array}{l}\text { In your classes, how often do you use the following instruc- } \\
\text { tional methods? } \\
\text { Lecture, guest speaker, brainstorming, videos, class dis- } \\
\text { cussion, small group discussion, case studies, hands- } \\
\text { on/interactive activities, critical thinking activities }\end{array}$ & $\begin{array}{l}\text { Representation; } \\
\text { Engagement }\end{array}$ & $\begin{array}{l}\text { Flexibility in use; Community of } \\
\text { learners (for class discussion } \\
\text { and small group discussion) }\end{array}$ \\
\hline $\begin{array}{l}\text { I give students (with or without disabilities) a choice in as- } \\
\text { sessment methods (e.g., taking a test, writing a paper, or } \\
\text { online project) }\end{array}$ & Expression & Flexibility in use \\
\hline I follow my syllabus closely & & $\begin{array}{l}\text { Simple and intuitive; Perceptible } \\
\text { information }\end{array}$ \\
\hline $\begin{array}{l}\text { I give an option to turn in individual project components for } \\
\text { feedback for later integration into a final project }\end{array}$ & Expression & Tolerance for error \\
\hline Class outline or lecture slides are provided prior to class & $\begin{array}{l}\text { Engagement; } \\
\text { Representation }\end{array}$ & $\begin{array}{l}\text { Equitable use; Low physical } \\
\text { effort }\end{array}$ \\
\hline $\begin{array}{l}\text { I ensure that the classroom is arranged so that it is } \\
\text { approachable and accessible }\end{array}$ & & $\begin{array}{l}\text { Size and space; Low physical } \\
\text { effort }\end{array}$ \\
\hline I provide personal feedback as needed & Engagement & $\begin{array}{l}\text { Tolerance for error; Community } \\
\text { of learners; Instructional climate }\end{array}$ \\
\hline Communication and interaction among students is observed & Engagement & Community of learners \\
\hline I am available to students outside of class & Engagement & Instructional climate \\
\hline Am willing to provide accommodations* & & Equitable use \\
\hline
\end{tabular}

